\title{
Vulnerability of Displaced Women and Children to HIVIAIDS in West Africa Gloria Cooper**
}

Address: United Churches of the World

Email: Gloria Cooper* - gloriacooper2005@yahoo.com

* Corresponding author ‡Presenting author

from 2005 International Meeting of The Institute of Human Virology

Baltimore, USA, 29 August - 2 September 2005

Published: 8 December 2005

Retrovirology 2005, 2(Suppl I):PI52 doi:I0.I I86/I742-4690-2-SI-PI52

\section{Background}

West Africa is considered to be the most unstable region on the Africa continent. Civil wars in Liberia, Sierra Leone and Ivory Coast couple with political instability in Nigeria, Guinea Bissau and recently Togo have put Women and children at risk to diseases and poverty. These women struggled with their in order to meet the basic necessity of life. We take this as a serious problem because according to Church World service "refugees and internally displaced persons are six times more likely to get infected with the virus than their counterparts in normal condition.

\section{Methods}

There were wide ranging places that our assessment covered. We were in the market places, Night clubs and bars as well as schools and the most important of all we were from door to door. This was a long a hectic process that took more than six months.

Questions were being asked in the form of conversation and at some time for the literates questionnaire were issued to be filled in. Gifts were given to people at times for encouragement. Children at various schools were allowed to have time to discuss AIDS and some causes among women and young girls.

\section{Results}

After visiting the Liberian Refugee Camps in Ghana and the Ivory Coast and also displaced camps in Liberia Guinea and Sierra Leone several data were collected which are clear representation of the vulnerability of women and young girls.
About $80 \%$ of the women told us that they get involved in risky sexual behaviour inorder to keep up their children. Also about $72 \%$ of young girls get involved in sexual behaviour because of the pressure from men and also rape. Ten percent told us that whenever they drink alcohol the feel like indulging in sexual activity. The location of wells and market places as well as the closeness of the houses are factors that increase their vulnerability.

\section{Conclusion}

After this assessment it can be concluded that the main causes of the growing rate of infection in the sub region is poverty and instability. The only way to solve this is to first have political stability in the region where people will go through the normal education process and become soundly education. If they are sound they will not be too greedy for power to the detriment of the masses. There are enough resources that can be exploited in order to feed the people of the sub region. The international community should think on stability before fighting the virus. 